\title{
PENGADAAN TANAH UNTUK KEPENTINGAN UMUM (PERSPEKTIF AL-QUR'AN)
}

\section{Musleh Herny}

Fałudtas Syariah Uniersitas Islam Negeri (UIN) Matang.

A. Gajayana 50 Malang, telp. 0341- 551354

\section{Abctract}

Al-Qur'an and of Hadist represent guidance of public or made hold according to Islam about levying of land for the sake of public. In al qu'ran, expressed that Allah bestow big grant from above to human being by creating earth, natural resources and water which consist in in it to human being to be used human being to be able to take care of the continuity of its life and so that human being devote to Allah of SWT, to family and to society. By its, land eksistensi have to be utilized to its of prosperity of society as arranged in Section 33 sentence (3) UUD 1945.

Key wordss lewying of land, public interest, society.

\section{Pendahuluan}

Bangsa yang hidupnya berlandaskan Ketuhanan Yang Maha Esa (sila pertama Pancasila) diajarkan dalam kehidupan untuk saling menyayangi satu sama lain dengan tidak melihat perbedaan, akan tetapi dalam

Ulul Albab, Vol. 9 No. 2, 2008 
empiriknya seringkali memusuhi pihak yang paling dikasihi Tuhan (rakyat miskin dan tertindas). Padahal Hukum Islam sendiri punya komitmen untuk berpihak kepada mereka yang lemah dan teraniaya, bukan sebaliknya yang mendukung kekuasaan dengan membackupnya melalui simbol-simbol keagamaan.

Masih banyak fenomena serupa yang terjadi di setiap sudut tanah air ini: penggusuran, ganti rugi tanah yang tidak adil, perampasan hak, dll. Tapi seolah telah menjadi hal yang biasa, berbagai tindak kezaliman dan ketidakadilan itu telah dianggap sebagai tindakan pembangunan dan pengorbanan untuk kesejahteraan bersama (tetapi siapa yang akhirnya sejahtera).

Untuk pengadaan tanah oleh pemerintah daerah haruslah diabadikan kepada kepentingan dan kesejahteraan rakyat dan sekaligus menciptakan pertumbuhan ekonomi dan kemampuan untuk berdiri di atas kekuatan sendiri menuju masyarakat adil dan makmur berdasarkan Pancasila. Dengan adanya otonomi daerah pemerintah daerah diberi hak oleh undang-undang untuk mengatur, mengisi, dan menetukan arah pembangunan daerah, perlu mengambil langkah-langkah dan tindakan-tindakan yang tegas guna melindungi dan menjaga kelestarian sumber daya alam tersebut.

Oleh karena itu usaha-usaha dan tindakan-tindakan untuk menjaga melindungi dan memanfaatkan sumber daya alam tersebut harus dibuat suatu kebijakan sebagai landasan hukum yang tegas dan jelas, lengkap serta menyeluruh guna menjamin adanya kepastian hukum bagi kepentingan masyarakat dan negara (Hamzah, 2006: 10).

UUPA merupakan sarana hukum untuk membawa kemakmuran dan kesejahteraan serta keadilan bagi negara dan masyarakatnya dalam rangka mewujudkan masyarakat adil dan makmur dan berorientasi untuk kesejahteraan masyarakat yang berkeadilan sosial, maka manusia Indonesia harus memahami dirinya sebagai mahkluk individu dan sosial yang mendasarkan atas keadilan dan kemanfataan tanah bagi kepentingan perseorangan maupun masyarakat (Erwiningsih, 2000: 15).

Ulul Albab, Vol. 9 No. 2, 2008 
Melihat hakikat otonomi daerah itu sendiri, artinya daerah itu mempunyai hak untuk mengatur rumah tangganya sendiri. Oleh karenanya pembuat UUNo. 32 tahun 2004 menduduk-letakkan pemerintahan daerah (kabupaten/kota) sebagai locus otonomi (Zakaria, 2001: 51). Dengan demikian, Bupati/Walikota sebagai pimpinan badan eksekutif suatu pemerintah daerah mempunyai wewenang untuk melakukan perbuatan hukum (rechushandeling) dan/atau keputusan hukum (rechtsbesluiten). Dalam rangka melaksanakan upaya pengadaan tanah oleh pemerintah daerah harus ditempuh melalui mekanisme dan prosedur yang ada di daerah tersebut.

Tulisan ini akan menyorot problem pengadaan tanah untuk kepentingan umum, pengadaannya sering melibatkan masyarakat dengan penguasa pemerintah yang akan ditinjau dari perspektif Hukum Islam.

\section{Pengadaan Tanah untuk Kepentingan Umum dalam Al-Qur'an}

Pedoman umum yang akan dijadikan pegangan menurut Islam tentang pengadaan tanah untuk kepentingan umum, tidak terlepas dari alQur'an, Hadits yang diriwayatkan oleh ahli hadits dan risalah Rasulullah SAW.

Dalam al-Qur'an, dinyatakan bahwa Allah menganugerahkan karunia yang besar bagi manusia dengan menciptakan bumi, air dan kekayaan alam yang terkandung di dalamnya bagi manusia untuk digunakan manusia untuk dapat menjaga kelangsungan hidupnya dan agar manusia berbakti kepada Allah SWT, kepada keluarga dan kepada masyarakat.

Di dalam ayat-ayat al-Qur'an surah al-Baqarah ayat 29 , dinyatakan:

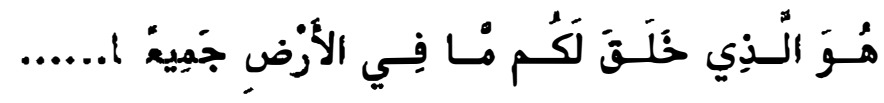

Dia-lah Allah, yang menjadikan segala yang ada di bumi untuk kamu......... " (QS. al-Baqarah: 29). 
Menurut Hukum Islam, hubungan antara penguasa sebagai suatu badan hukum (publik) dengan pemegang hak atas tanah sebagai orang yang dikuasai ialah, penguasa dapat memperoleh hak atas tanah sebagaimana halnya dengan badan hukum (privat) lainnya. Caranya, dengan melakukan hubungan hukum 2 (dua) pihak dengan pemegang hak atas tanah dengan jual beli, tukar menukar dan hubungan-hubungan hukum lainnya yang dapat memindahkan hak atas tanah dalam hubungan keperdataan seperti ini harus dijamin adanya keseimbangan hak dan kewajiban antara para pihak. Pihak yang satu dilarang memaksakan kehendaknya kepada pihak yang lainnya.

Menurut hukum Islam cara jual beli biasa yang dianut pada waktu itu dapat dijadikan pedoman dalam pengadaan tanah yaitu jaminan kesukarelaan, dan jaminan keseimbangan hak dan kewajiban. Hal ini secara tegas diatur di dalam al-Qur'an.

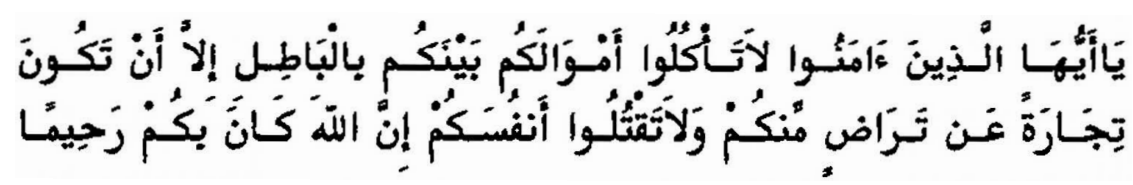

Hai orang-orang yang beriman, janganlah kamu saling memakan harta sesamamu dengan jalan yang batil, kecuali dengan jalan perniagaan yang berlaku dengan suka sama-suka di antara kamu. dan janganlah kamu membunuh dirimu; Sesungguhnya Allah adalah Maha Penyayang kepadamu (QS. an-Nisaa': 29).

Selanjutnya, berdasarkan hadits H.R.Muslim; dinyatakan bahwa sesungguhnya darah dan hartamu haram bagi sesama kamu, sampai kamu kembali kepada Tuhanmu. Tidak halal bagi seseorang mengambil harta saudaranya kecuali dengan ketulusan hati saudaranya (Khudari, 1989: 97).

Untuk memperoleh pemahaman tentang perbuatan nyata dalam hukum Islam, ada baiknya dikaji ulang sejarah Nabi Muhammad SAW beserta sahabat-sahabatnya pindah (hijrah) ke Madinah. Sewaktu Rasulullah memasuki Madinah, kaum Anshar mengeluk-elukkan beliau serta 
menawarkan rumah untuk istirahat. Namun Rasulullah SAW menjawab dengan bijaksana: "Biarlah jalan unta ini, karena ia diperintah." (Khudari, 1989: 98).

Rasulullah SAW melanjutkan perjalanan, dan unta beliau berhenti (mendekam) di atas sebidang tanah milik dua orang anak yatim yang bernama Sahal dan Suhail, keduanya anak dari Amr bin Amarah di bawah pemeliharaan As'ad ibnu Zarzarah. Tempat itu adalah penjemuran kurma milik dua orang anak laki-laki yatim itu. Oleh Abu Ayub al Anshari untuk tinggal di rumahnya. Setelah beberapa bulan di sana, beliau merencanakan untuk mendirikan masjid. Tempat yang dipilih adalah bekas mendekamnya unw beliau.

Rasulullah SAW memanggil kedua anak yatim tersebut dengan maksud ingin membeli tanah itu guna tempat mendirikan masjid. Kedua anak itu bertahan tidak menjual tanahnya kepada Rasulullah SAW, kecuali hanya bersedia mewakafkannya. Akan tetapi beliau juga bertahan tidak mau mengambil begitu saja tanah itu, walaupun dalam bentuk wakaf. Beliau tidak mau mengambil tanah itu sebagai pemberian, tetapi beliau hendak mem-belinya. Pada akhirnya beliau berhasil membeli tanah itu dari tangan kedua anak yatim itu dengan harga yang di sepakati yaitu, sebesar sepuluh dinar, dan yang membayarnya adalah Abu Bakar (Khudari, 1989: 39).

Dari uraian ini, difahami bahwa Rasulullah SAW tidak mengambil begitu saja tanah seseorang, melainkan dengan membelinya dengan harga yang wajar, walaupun sesungguhnya orang tersebut menyerahkannya secara cumacuma karena mereka sadar bahwa tujuannya adalah guna kepentingan umum.

Berdasarkan ayat-ayat al-Quran, Hadits Rasulullah SAW dan risalah Nabi Muhammad SAW dapat dipahami bahwa menurut ajaran Islam, tetap dibenarkan adanya penggunaan tanah orang lain untuk kepentingan umum. Hukum Islam sangat menghormati hak milik orang lain, dan dengan me $ı$ hargainya secara wajar. Walaupun penggunaanya untuk kepentingan umum, akan tetapi tanah tidak diambil begitu saja, melainkan dengan ganti 
kerugian yang wajar. Prosesnya adalah sesuai dengan aturan-aturan perniagaan yang berlaku dan dilakukan secara sukarela.

Negara-negara Islam yang tergabung di dalam The Organizaion of te Islamic Confrece (OIC) telah mengeluarkan deklarasi tentang kemanusiaan sesuai syariat Islam sebagai satu-satunya sumber acuan yang berlandasan alQur'an dan sunnah (Lopa, 1996: 102).

Konsep hak-hak asasi manusia itu disebur Cairo Declaration (CD) karena deklarasi itu lahir di Kairo pada tanggal 5 Agustus 1990. Dalam Pasal 15 CD di nyatakan bahwa:

a. Every one shall have the right to own property acquired ini a legitime way, and shall be entitled to the rights of the ounership, without prejudice to oneself, other or to society ini general. Expropriation is not permisible except for the requirements of public interest and upon payment of immediate and fair compensation. (Semuanya akan mempunyai hak untuk memiliki suatu hak milik yang diperoleh dengan cara suatu legitime, dan akan menjadi hak kepemilikan, tanpa berkewajiban terhadap dirinya, atau kepada masyarakat umum. Pengambilalihan bukanlah permisible kecuali kebutuhan kepentingan publik (umum) dan atas pembayaran ganti-rugi yang adil dan segera).

b. Confiscation and seizure of property is prohibited expect for a nessessity dictated by law, (Penyitaan dan perampasan hak milik dilarang diharapkan untuk suatu nessessity mengajukan permohonan di depan hukum) (Lopa, 1996: 104).

\section{Teologi Tanah dan Kekayaan Alam}

Allah SWT telah menciptakan bumi (tanah) untuk kepentingan kehidupan seluruh makhluk Allah yang ada dipermukaan bumi ini. Sebagaimana tertuang dalam Pasal 1 ayat (2) UUPA bahwa "seluruh bumi, air dan ruang angkasa, termasuk kekayaan alam yang terkndung di dalam wilayah Republik Indonesia sebagai Karunia Tuhan Yang Maha Esa......". oleh karena bumi diciptakan oleh Allah utuk semua umatnya, maka 
ditekankan bahwa bumi (tanah) itu harus dikelola secara adil untuk sebesarbesarnya kemakmuran dan kesejahteraan masyarakat. Uraian di atas dapat dilihat dalam beberapa ayat al-Qur'an sebagai berikut

1. Surat al-Rahman ayat 10 , yaitu:



Bumi diciptakan oleh Tuhan untuk semua makhluk.

2. Surat al-A'raf ayat 24 , yaitu:



Bumi diciptakan sebagai tempat hidup dan fasilitas bagimu hingga kini.

3. Surat al-A'raf ayat 74 , yaitu:

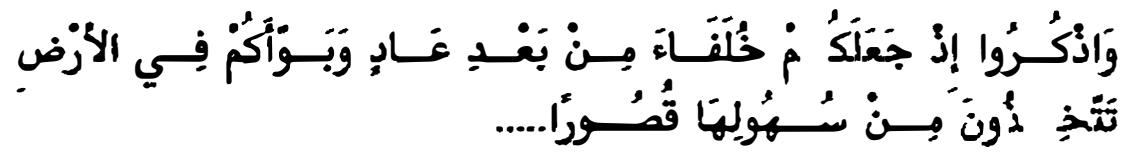

Ingatlah, ketika Aku (Allah) jadikan dirimu sebagai penguasa sesudah kaum 'Ad dan menjadikan bumi sebagai tempat hidup bagimu. Lembah dan ngarainya kamu jadikan tempat tinggal......

Dalam pengelolaan bumi/tanah beserta seluruh kekayaan alam adalah tugas seluruh umat manusia dan tidak diperbolehkan untuk dimonopoli sekelompok orang tertentu (para pemilik modal), jika hal itu terjadi akibatnya tidak saja akan merugikan masyarakat secara umum, tetapi keseimbangan alam menjadi terancam, sebagai akibat ulah manusia yang serakah, mani-pulatif dan eksploitatif itu. Maka jangan salahkan Tuhan ketika menurunkan bencana itu kepada umat manusia, sebagaimana disampaikan-Nya dalam al-Qur'an sebagai berikut:

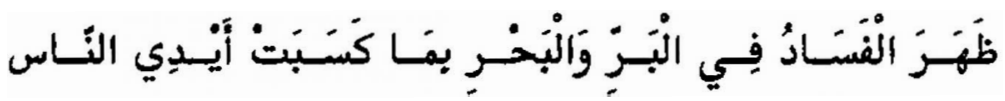

Ulul Albab, Vol. 9 No. 2, 2008 
Telah nyata kerusakan (timbul bencana) di darat maupun di lautan akibat dari ulah manusia (yang eksploitatif, serakah)..." (QS. arRum: 41).

Dalam al-Qur'an banyak ayat yang memperingatkan kepada manusia untuk tidak melakukan tindakan yang merusak harmoni alam. Penciptaan alam raya termasuk lingkungan kosmos manusia (tanah, air dan udara) adalah telah ditentukan qadar (ukuran, hukum)-Nya, sehingga merusaknya adalah berarti merusak qadar Allah. Dalam al-Qur'an surat dinyatakan:

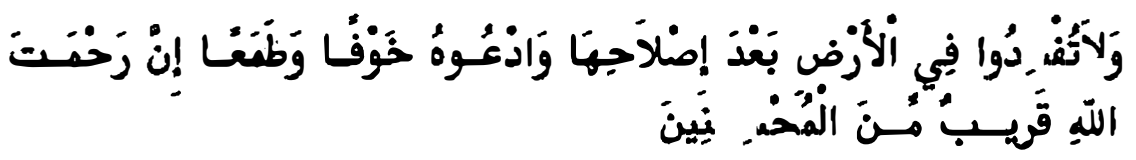

Dan janganlah kamu membuat kerusakan di muka bumi, sesudah (Allah) memperbaikinya (reformasi) dan berdoalah kepada-Nya dengan rasa takut (Tidak akan diterima) dan harapan (akan dikabulkan). Sesungguhnya rahmat Allah amat dekat kepada orangorang yang berbuat baik (QS. al-A'raf: 56).

Ungkapan "janganlah berbuat kerusakan di muka bumi sesudah direformasi" dalam surat al-A'raf ayat 56 diatas- mengandung makna ganda, yaitu:

1. Larangan merusak bumi setelah perbaikan (ishlah) yaitu saat penciptaan bumi oleh Allah sendiri. Makna ini menunjukkan tugas manusia untuk melindungi bumi itu yang sudah merupakan tempat yang baik bagi hidup manusia. Jadi tugas reformasi berkaitan dengan usaha pelestarian lingkungan hidup yang sehat dan alami.

2. Larangan membuat kerusakan di bumi setelah terjadi reformasi atau perbaikan oleh sesama manusia. Hal ini bersangkumn dengan tugas reformasi aktif manusia untuk berusaha menciptakan sesuatu yang baru, yang baik (shalih) dan membawa kebaikan (mashlahah) untuk manusia. Tugas kedua ini, lebih berat dari tugas pertama, memerlukan pengertian yang tepat tentang hukum-hukum Allah SWT yang menguasai alam ciptaan- 
Nya, diteruskan dengan kegiatan bertindak sesuai dengan hukum-hukum itu melalui rekayasa tehnologi (technological engineering). Lebih dari tugas pertama, pemanfaatan alam ini harus dilakukan dengan daya cipta dan kreasi yang tinggi, dan dengan menggunakan prinsip-prinsip keseimbangan.

Reformasi dunia yang diajarkan oleh al-Qur'an berlandasakan pada prinsip keadilan dan kejujuran, khususnya dalam kegiatan sosialekonomi yang melibatkan proses pembagian kekayaan dan pemerataannya antara warga masyarakat, sebab dunia yang sudah direformasi itu tidak boleh mengenal terjadinya perolehan kekayaan secara tidak sah dan tidak adil. Bahkan juga tidak boleh terjadi penumpukan kekayaan begitu rupa (kapitalisasi) sehingga harta benda dan sumber hidup masyarakat beredar diantara orang-orang yang kaya saja dalam masyarakat.

Aneka kebijakan pengadaan tanah untuk pembangunan yang notabenenya dimiliki oleh rakyat jelata dan papa, diamini oleh ulama rezim dengan dalih untuk kemashlahatan umum. Tentu saja ini fenomena yang sangat mencengangkan, dilihat dari perspektif peran ulama yang semestinya lebih berpihak kepada rakyat kecil ketimbang penguasa yang sering menindas rakyamya. Sehingga fiqih yang keluar dari pemikiran ulama model ini sarat dengan kepentingan kelas tertentu, dan sama sekali tidak menyentuh akar kebutuhan rakyat.

Telah diuraikan di atas, bahwa seringkali dengan dalih pembangunan, maka perampasan terhadap hak masyarakat menjadi sesuatu yang dianggap biasa atau tidak masalah, bahkan ini harus, karena pambangunan selalu berorientasi kepada "kepentingan umum". Kepentingan umum dalam konteks ini terasa sangat kabur dan bias, apalagi yang dibangun itu seperti pembangunan mall, tempat hiburan, pabrik industri, padang golf dan sebagainya, bukankah hal tersebut merupakan simbol-simbol atau perangkat kapitalisme dan masyarakat yang mana yang akan menikmati pembangunan macam ini.

Akan tetapi dalam pembangunan untuk "kepentingan umum" tentunya ada yanyू memang betul-betul untuk kepentingan umum, misalnya 
dalam pembangunan jalan, waduk irigasi, sekolah, rumah sakit dan fasilitas umum lainnya. "Kepentingan umum" dalam konteks ini harus diwujudkan, tetapi tetap dengan cara-cara yang benar-benar adil dan tidak ada pihak yang dirugikan. Hal ini dapat dilihat dalam Peraturan Presiden Nomor 65 tahun 2006 Pasal 5 dan Pasal tentang Ganti rugi yang diberikan kepada pemilik tanah dalam kasus ini harus tetap proporsional dan manusiawi, sembari tetap melakukan negosiasi dengan prinsip-prinsip at-taradli dan syura. Fikih menyebut hal ini sebagai istimlak bi alqimmah, penguasaan hak orang lain dengan ganti rugi.

Contoh yang secara eksplisit disebutkan dalam kitab kuning adalah, ketika ada sebuah masjid yang sudah tidak lagi memuat jamaah dan sudah sangat mendesak untuk diperluas, tetapi dengan konsekwensinya harus mengorbankan tanah warga yang berada di samping masjid. Apakah boleh memaksa pemilik tanah untuk menyerahkan tanahnya? Para fuqaha menjawabnya: Boleh, dengan syarat pemilik tanah harus mendapat ganti rugi yang layak.

Ketentuan fikih ini tidak untuk memberi peluang tindah sewenangwenang pemerintah terhadap rakyat. Tidak pula untuk mengabsahkan peng-uasaan pemodal besar atas rakyat kecil. Meskipun sudah jelas bahwa proyek yang hendak dilaksanakan adalah demi almashlahah al'ammah (المـلحن الاهـ), tetapi tetap diperlukan musyawarah untuk menetapkan harga ganti rugi. Al-Qur'an memberi petunjuk: la tadzlimuna evala tudzlamun

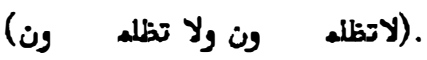

Jadi, sesungguhnya ada dua hal yang perlu dipastikan dalam penggusuran tanah rakyat. Pertama, apakah tanah itu memang dibutuhkan untuk proyek pemerintah yang manfaatnya untuk kepentingan umum (almashlahah al'ammah/ (اله لمحة الايسة). Kedua, apakah telah ada kesepakatan harga antara pemilik tanah dengan pelaksana proyek. Jika kedua syarat ini tidak dipenuhi, maka tidak ada pembenaran bagi pihak manapun untuk menggusur tanah milik rakyat, dan pada saat yang sama, rakyat wajib mempertahankan dengan cara apapun, sekalipun harus mengorbankan jiwa. Ini sejalan dengan pesan Rasulullah: "Jika kamu 
terbunuh (saat mempertahankan hak milikmu) maka kamu mati syahid, dan kalau mereka yang terbunuh maka dia masuk neraka".

Di luar itu maka tidak ada peluang sama sekali untuk melakukan penggusuran tanah rakyat dengan dalih apapun, jika ini yang terjadi, adalah tindakan dzalim yang dosanya teramat besar. Memerangi kedzaliman adalah kewajiban agama. Maka jangan ada rasa takut dan khawatir untuk selalu membela mereka yang lemah (dhu'afa) dan dilemahkan (mustadh'afin), karena Allah memerintahkan: ولا تخنـــــ ("janganlah kamu takut kepada mereka (yang dzalim) tetapi takutlah kepadaku (jika kamu tidak memerangi mereka)".

Al-Qu'an mendefinisikan zhalimun, para penindas, adalah orang-orang yang mengingkari Allah (juga kebenaran, keadilan dan kesetaraan). Mereka adalah "yang ingkar akan tanda-tanda Allah dan membunuh nabi-nabi tanpa sebab dan membunuh mereka yang menyunch orang berbuat adil ..". Al-Qu'an mengumpamakan keadaan para penindas itu seperti panen yang gagal karena dirusak oleh hawa yang membeku:

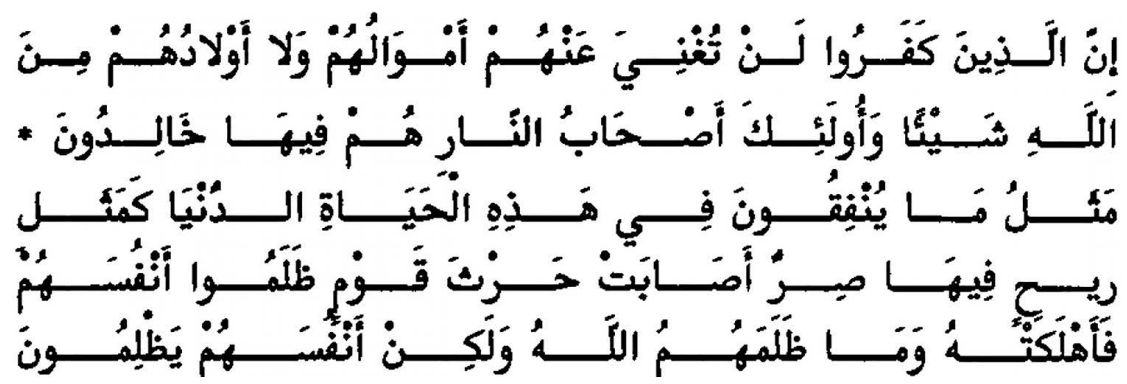

Mereka yang kafir, harta dan anak-anak mereka yang sedikitpun tak berguna dalam pandangan Allah. Mereka menghuni api neraka, di sana mereka tinggal selama-lamanya. Perumpamaan segala apa yang mereka nafkahkan dalam hidup di dunia ini seperti angin dingin menimpa tanaman suatu golongan yang menganiaya diri. Bukan Allah yang menganiaya mereka tetapi mereka menganiaya diri sendivi" (Q.S. ali-Imran: 116-117).

Ulul Albab, Vol. 9 No. 2, 2008 


\section{Pengadaan Tanah untuk Kepentingan Umum menurut Hukum Positif}

\section{à. Pengertian Pengadaan Tanah}

Dewasa ini ketersedian tanah-tanah negara yang "bebas" sangat terbatas. Dengan kata lain, tanah-tanah di Indonesia sekarang ini pada umumnya sudah dimiliki atau setidak-tidaknya ada yang ada mendudukinya. Konsekuensinya, jika ada kegiatan pembangunan yang membutuhkan tanah, maka tanah itu harus diperoleh dengan tindakan pengambilalilan tanah/pengadaan tanah.

Demi kepentingan umum, pemerintah mempunyai kewenangan konstitusional untuk memperoleh tanah dari pemilik tanah. Prinsip-prinsip yang mendasari pengadaaan tanah oleh pemerintah tersebut mengacu pada pribahasa (maxim):

a. kepentingan umum lebih besar daripada kepentingan pribadi

b. penguasa dan negara, dengan alasan yang layak/memadai, dapat mengambilaliah kepentingan pribadi.

c. hukum mewajibkan seseorang untuk mendahulukan kepentingan negara daripada keselamatan pribadinya.

Secara teoritis, pengadaan tanah (land acquisition) terdiri atas pengadaan tanah secara sukarela (Valuntary acquisition of land) yang meliputi, antara lain: pemindahan hak dan pelepasan atau penyerahan hak (Perpres No. 36 tahun 2005 dan Perpres No. 65 tahun 2006) dan pengadaan tanah secara wajib (compulsory acquisition of land) adalah pencabutan hak atas tanah (UU No. 20 tahun 1961) (Brown, 1996: 1).

Landasan konstitusional kebijakan pembangunan bidang pertanahan pada intinya bersumber pada ketentuan UUD 1945 Pasal 33 ayat (3). Kemudian diundangkan UU Nomor 5 tahun 1960 tentang Peraturan Dasar Pokok-Pokok Agraria (dikenal UUPA) (Chomzah, 2003: 13). Dalam Keputusan Presiden No. 36 tahun 2005 Pasal 1 butir 3, menyatakan bahwa yang dimaksud dengan pengadaan tanah adalah setiap kegiatan untuk 
mendapatkan tanah dengan cara memberikan ganti rugi kepada yang melepaskan atau yang menyerahkan tanah, bangunan, tanaman, dan bendabenda yang berkaitan dengan tanah atau dengan pencabutan hak atas tanah.

Diperjelas lagi dalam Konsideran "menimbang a ${ }^{n}$ Keputusan Presiden No. 36 tahun 2005 menyatakan bahwa dengan meningkatkannya pembangunan untuk kepentingan umum yang memerlukan tanah, maka pengadaannya perlu dilakukan secara cepat dan transparan dengan tetap memperhatikan prinsip penghormatan terhadap hak-hak yang sah atas tanah. Hal tersebut berarti bahwa dalam pengadaan tanah, di satu pihak harus diingat adanya fungsi social dari tanah, yaitu: harus diabadikan dalam kehidupan masyarakat banyak (bangsa/negara), namun di lain pihak kepentingan pihak yang telah memiliki hubungan hukum dengan tanah tersebut pun harus tetap dihormati serta harus dilakukan secara transparan.

Pada garis besarnya pengadaan tanah dikenal dengan dua jenis pengadaan tanah, yaitu: pengadaan tanah untuk keperluan pemerintah dan pengadaan tanah untuk keperluan swasta (Soegiarto, 1994: 10). Pengadaan tanah yang dilakukan oleh pemerintah dibagi atas pengadaan tanah bagi kepentingan umum dan bukan kepentingan umum (misalnya: kepentingan komersial).

Dengan ditetapkan Keputusan Presiden No. 36 tahun 2005, pengadaan tanah untuk kepentingan umum hanya dapat dilakukan oleh pemerintah dengan melalui kesepakatan antar pihak. Tegasnya bahwa pengadaan tanah dalam keadaan biasa tidak bisa dilakukan dengan cara paksa. Pencabutan hak atas tanah baru dilakukan jika acara pelepasan hak benar-benar gagal, sementara lokasi pembangunan yang akan dilaksanakan tidak bisa dipindahkan. Dengan kata lain, pencabutan hak atas tanah sebagai cara paksa pengadaan tanah hanya dilakukan dalam keadaan memaksa.

\section{b. Pengertian Kepentingan Umum}

Bagi manusia tanah merupakan hal terpenting bagi hidup dan kehidupanya. Bukanlah hal yang mengherankan apabila setiap orang pasti 
mempunyai keinginan untuk dapat memiliki tanah lengkap dengan perlindungan hukumnya. Perlindungan itu diwujudkan dengan pemberian berbagai macam hak atas tanah oleh Negara sebagai petugas pengatur, dan perlu dibentuk perundang-undangan yang jelas dan tegas (Sutedi, 2007: 45).

Fungsi dan peran tanah dalam berbagai sektor kehidupan manusia memiliki tiga aspek yang sangat strategis, yaitu: aspek ekonomi, politk dan hukum, dan aspek social (Winangun, 2004: 21). ketiga aspek tersebut merupakan isu sentral yang paling terkait sebagai satu kesatuan yang terintegrasi dalam pengambilan proses kebijakan hukum pertanahan yang dilakukan oleh pemerintah (Idham, 2004: 76).

Secara sederhana menurut Salindeho bahwa kepentingan umum dapat saja diartikan atau dikatakan untuk keperluan, kebutuhan atau keperluan orang banyak atau tujuan social yang luas (Salindeho, 1988: 40). Rumusan di atas pada prinsipnya sama dengan pengertian yang diberikan oleh UUPA dan UU No. 20 tahun 1961.

Maria SW. Sumardjono menyatakan bahwa UUPA, dan UU No. 20 tahun 1961 belum menegaskan esensi kreteria kepentingan umum secara konseptual. Di dalam UUPA dan Undang-undang Nomor 20 tahun 1961, kepentingan umum dinyatakan dalam arti "peruntukannya", yaitu: kepentingan bangsa dan Negara, kepentingan bersama dari rakyat, dan demikian untuk kepentingan pembangunan. Sedangkan dalam Perpres Nomor 36 tahun 2005 Pasal 1 butir (5) merumuskan bahwa kepentingan umum adalah kepentingan sebagian besar lapisan masyarakat.

Yang menjadi masalah adalah kepentingan umum "siapa", bila suatu kegiatan sudah terwujud dan ternyata kemanfaatannya tidak dapat dirasakan oleh masyarakat? Oleh karena itu, Maria S.W. Sumardjono mengusulkan agar konsep kepentingan umum, selain harus memenuhi "peruntukannya", juga harus dapat dirasakan "kemanfaatannya" (socially profitable atau for public use, atau actual used by the public) (Sumardjono, 1990: 13). 
Perpres Nomor 65 tahun 2006 memberi klarifikasi pengertian kepentingan umum. Pasal I butir 5 Perpres di atas merumuskan bahwa kepentingan umum adalah kepentingan sebagian besar lapisan masyarakat. Selanjutnya Pasal 5 Perpres di atas bahwa pembangunan untuk kepentingan umum dibatasi untuk "...Kegiatan pembangunan yang dilakukan dan selanjutnya dimiliki atau akan dimiliki oleh pemerintah atau pemerintah daerah".

Jelaslah bahwa Perpres Nomor 65 tahun 2006 tidak sekedar memperhatikan "kemanfaatan" dari kepentingan umum, namun juga membatasi "siapa" yang menjadi pelaksana pembangunan kepentingan umum (dilakukan dan selanjutnya dimiliki Pemerintah).

Namun salah satu persoalan yang masih dihadapi sehubungan dengan pelaksanaan kepentingan umum adalah menentukan titik keseimbangan antara kepentingan umum dengan kepentingan pribadi di dalam pembangunan (Mahendra, 1996: 56). Sejalan dengan pemikiran Notonegoro bahwa kepentingan umum hendaknya seimbangan dengan kepentingan individu (Notogegoro, 2001: 12).

Dengan adanya pengadaan tanah untuk kepentingan umum sebagai akibat dari Pasal 6 UUPA yang menyatakan bahwa semua hak atas mengandung fungsi sosial (kepentingan umum). Timbulnya pengertian fungsi sosial adalah sebagai reaksi dai penerapan dan penggunaan hak milik secara mutlak dan formalistis. Dalam Pasal 33 ayat (3) UUD 1945 ditetapkan dengan bumi, air dan kekayaan di dalamnya dikuasai oleh negara dan dipergunakan sebesar-besarnya untuk kemakmuran rakyat. Untuk mencapai tujuan sebesarbesarnya untuk kemakmuran rakyat, harus ada penguasaan negara

\section{Simpulan}

Menurut Hukum Islam, penguasa dapat memperoleh hak atas tanah dengan melakukan cara jual beli, tukar menukar dan hubungan-hubungan hukum lainnya yang dapat memindahkan hak atas tanah.dan harus dijamin adanya keseimbangan hak dan kewajiban antara para pihak./ pihak yang satu dilarang memaksakan kehendaknya kepada pihak yang lainnya. Berdasarkan 
Hukum Islam, dibenarkan adanya penggunaan tanah orang lain untuk kepentingan umum. Hukum Islam sangat menghormati hak milik orang lain, dan dengan menghargainya secara wajar. Akan tetapi tanah tidak diambil begitu saja, melainkan dengan ganti kerugian yang wajar, sedangkan prosesnya sesuai dengan aturan-aturan perniagaan yang berlaku dan dilakukan secara sukarela.

Hal tersebut di atas sejalan denganp penyataan dalam Keputusan Presiden No. 36 tahun 2005 Pasal 1 butir 3, menyatakan bahwa yang dimaksud dengan pengadaan tanah adalah setiap kegiatan untuk mendapatkan tanah dengan cara memberikan ganti rugi kepada yang melepaskan atau yang menyerahkan tanah, bangunan, tanaman, dan bendabenda yang berkaitan dengan tanah atau dengan pencabutan hak atas tanah. Pelaksanaan pengadaan tanah bagi pembangunan untuk kepentingan umum seharusnya mengacu pada aturan yang diatur dalam Hukum Islam. Agar tidak terjadi kerugian masyarakat yang terkena program pembangunan tersebut. Dengan kata lain, apabila pemerintah akan melaksanakan pembangunan dengan tujuan untuk kepentingan umum syogyanya pelaksanaan pengadaan tanahnya mengacu pada aturan dalam hukum Islam, bukan hanya diatas kertas saja bahwa pengadaan tanah untuk kepentingan umum harus meperhatikan hak-hak pemilik tanah, tetapi dalam pelaksanaannya banyak merugikan pemilik tanah.

\section{Daftar Pustaka}

Brown, D. 1996. Land Acquisition An examination of the principles of law and New Zealand, Edisi ke-4. Butterworths: Sydney-Adelaide-BrisbaneCamberra-Melbourne-Perth.

Erwiningsih, W. 1989. Aktualisasi Hukum Agraria Guna Menunjang Otonomi Daerah. Jurnal Hukum Volume ke-7, nomor 12: 81.

Hamzah, A. Dkk. 2006. Hukum Perumahan. Jakarta: Rineka Cipta.

Idham, H. 2004. Konsulidasi Tanah Perkotaan Dalam Perspektif Otonom Daerah, Cetakan l. Bandung: Alumni.

Khudari. 1989. Risalah Rasulullah. Jakarta: Penerbit Bulan Bintang. 
Lopa, B. 1996. Al-Qur'an dan Hak Asasi Manusia. Jakarta: Penertbit PT. Dana Bhakti Prima Yasa.

Notonegoro. 2001. Kebijakan Pertanahan Antara Regulasi dan Implementasi. Dalam Maria S.W (Ed.). Jakarta: Penerbit Kompas.

Salindeho, J. 1988. Masalah Tanah Dalam Pembangunan. Jakarta: Sinar Grafika.

Soegiarto, I. 1994. Kebijakan Umum Pengadaan Tanah Untuk Pembangunan, Makalah pada Seminar Nasional "Pegadaan Tanah Untuk Pembangunan, (Konsep Hukum, Permasalahan dan Kebijakan Dalam Pemecahannya)". Jakarta: Kerjasama FH. Univ.Trisakti dengan BPN.

Sutedi, A. 2007. Implementasi Prinsip Kepentingan Umum: dalam pengadaan tanah untuk pembangunan. Jakarta: Sinar Grafika.

Winangun, Y. 2004. Tanah Sumber Nilai Hidup, Cetakan I. Kanisius: Yogyakarta.

Zakaria, Y. et al. 2001. Mensiasati Otonomi Daerah Demi Pembahanuan Agraria. Yogyakarta: Lapera Pustaka Utama.

QS. al-A'raaf ayat (7) : $24 ; 56 ; 74$

QS. al-Baqarah (2) : 29

Q.S. ali Imran (3): $116-117$

QS. an Nisaa' (4) : 29.

QS. al-Rahman (55) : 10

QS. ar-Rum (30) : 41 